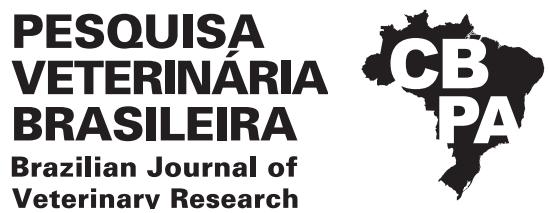

Pesq. Vet. Bras. 42:e06968, 2022

DOI: $10.1590 / 1678-5150-P V B-6968$

Original Article

Livestock Diseases

ISSN 0100-736X (Print)

(cc) BY-NC

ISSN 1678-5150 (Online)

\title{
Comparison of macroscopy, histopathology and PCR for diagnosing Eimeria spp. in broiler chickens ${ }^{1}$
}

\author{
Patrícia W.G. Balestrin², Eder Balestrin ${ }^{3}$, Fábio Santiani², Thierry G. de Cristo², \\ David G. Pereira², Gustavo R. Bonatto², João V. Bilick ${ }^{2}$ \\ and Renata A. Casagrande ${ }^{2 *}$ (i)
}

\begin{abstract}
Balestrin P.W.G., Balestrin E., Santiani F., de Cristo T.G., Pereira D.G., Bonatto G.R., Bilick J.V. \& Casagrande R.A. 2022. Comparison of macroscopy, histopathology and PCR for diagnosing Eimeria spp. in broiler chickens. Pesquisa Veterinária Brasileira 42:e06968, 2022. Laboratório de Patologia Animal, Centro de Ciências Agroveterinárias, Universidade do Estado de Santa Catarina, Av. Luís de Camões 2090, Lages, SC 88520-000, Brazil. E-mail: renata.casagrande@udesc.br

Coccidiosis is a disease of great importance in industrial poultry. The correct diagnosis directs the poultry industry to its best treatment and control. Thus, a survey of Eimeria spp. was carried out in intestines of 64 broiler flocks, with an average age of 29 days. Eight broilers from each flock were randomly removed from the slaughter line, in a total of 512 samples. Macroscopic and histopathological lesions in the intestine were classified into Scores 0 to 4 . Polymerase chain reaction (PCR) was used to research the oocysts from the seven species of Eimeria spp. in the intestinal content. The macroscopic evaluations showed that $59.4 \%(38 / 64)$ of the flocks were positive for E. acervulina, 32.8\% (21/64) for E. maxima, 29.7\% (19/64) for E. tenella, and $34.4 \%$ (22/64) for E. brunetti. The histopathological evaluation showed that $87.5 \%$ (56/64) of the flocks had at least one broiler with parasitic structures compatible with Eimeria spp. in the duodenum, $70.3 \%(45 / 64)$ in the jejunum, $18.8 \%(12 / 64)$ in the ileum, $46.9 \%(30 / 64)$ in the cecum, and $4.7 \%$ (3/64) in the colon. In PCR, 21.9\% (14/64) of the flocks were positive for E. acervulina, 12.5\% (8/64) for E. maxima, 3.1\% (2/64) for E. mitis, and 32.8\% (21/64) for E. tenella. The Kappa Cohen test between macroscopy, histopathology, and PCR demonstrated concordance ranging from weak to moderate with the exception of histopathology and PCR of the cecum, which was strong. In the comparison between macroscopy and histopathology, there were significative differences between Scores 0 and 1 (apart from the cecum). For Score 3, there were significative differences in duodenum, jejunum and cecum $(p<0.05)$. In conclusion, the macroscopic diagnosis and PCR can generate false-negative results, and the histopathological exam proved to be effective, making it essential to associate different techniques for the correct diagnosis of Eimeria spp. in broiler chickens.
\end{abstract}

INDEX TERMS: diagnosis, Eimeria spp., macroscopy, histopathology, PCR, broilers, coccidiosis, oocysts, pathology, enteric disease.

\section{RESUMO.- [Comparação da macroscopia, histopatologia} e PCR para o diagnóstico de Eimeria spp. em frangos de corte.] A coccidiose é uma doença de grande importância

\footnotetext{
${ }^{1}$ Received on September 13, 2021.

Accepted for publication on October 10, 2021.

${ }^{2}$ Graduate Program in Animal Science, Universidade do Estado de Santa Catarina (UDESC), Av. Luís de Camões 2090, Lages, SC 88520-000, Brazil. *Corresponding author: renata.casagrande@udesc.br

${ }^{3}$ Graduate Program in Cellular and Molecular Biology Applied to Health, Universidade Luterana do Brasil (ULBRA), Avenida Farroupilha 8001, Canoas, RS 92425-900, Brazil.
}

na avicultura industrial. 0 diagnóstico correto direciona a indústria avícola ao seu melhor tratamento e controle. Desta forma, realizou-se a pesquisa de Eimeria spp. em intestinos de 64 lotes de frangos de corte, com idade média de 29 dias. Em cada lote foram retirados aleatoriamente oito frangos da linha de abate, totalizando 512 . Os intestinos foram classificados na macroscopia e na histopatologia em Grau de 0 a 4 . No conteúdo intestinal pesquisou-se por reação em cadeia da polimerase (PCR) oocistos das sete espécies de Eimeria. As avaliações macroscópicas demonstraram que 59,4\% (38/64) dos lotes foram positivos para E. acervulina, 32,8\% (21/64) 
para E. maxima, 29,7\% (19/64) para E. tenella e 34,4\% (22/64) para $E$. brunetti. Na avaliação histopatológica, $87,5 \%$ (56/64) dos lotes apresentaram pelo menos um frango com estruturas parasitárias compatíveis com Eimeria spp. no duodeno, 70,3\% (45/64) no jejuno, 18,8\% (12/64) no íleo, $46,9 \%$ (30/64) no ceco e 4,7\% (3/64) no cólon. Na PCR 21,9\% (14/64) dos lotes foram positivos para E. acervulina, 12,5\% (8/64) para E. maxima, 3,1\% (2/64) para E. mitis e 32,8\% (21/64) para E. tenella. 0 teste de concordância de Kappa Cohen entre macroscopia, histopatologia e PCR demonstrou concordância variando de fraca a moderada com exceção da histopatologia e PCR do ceco que foi forte. Na comparação dos graus de macroscopia e histopatologia, foram encontradas diferenças significativas entre o Grau 0 e 1 (exceto no ceco) e no Grau 3 houve diferença para duodeno, jejuno e cecos $(p<0,05)$. Conclui-se que o diagnóstico macroscópico e a PCR podem gerar resultados falsos negativos e que o exame histopatológico se demostrou eficaz, tornando fundamental a associação de diferentes técnicas para o correto diagnóstico de Eimeria spp. em frangos de corte.

TERMOS DE INDEXAÇÃO: Macroscopia, histopatologia, PCR, diagnóstico, Eimeria spp., frangos de corte, coccidiose, oocistos, patologia, doença entérica.

\section{INTRODUCTION}

Coccidiosis is one of the most economically significant infectious diseases in industrial poultry and is caused by protozoa of the Eimeria genus that live intracellularly throughout the intestinal epithelium of poultries (Quiroz-Castañeda \& Dantán-González 2015). The infection is fecal-oral, occurring with the ingestion of sporulated oocysts, which invade and develop in the intestinal cells, changing their structures and villi. This reproduction process results in the loss of performance and increased mortality, causing a significant impact on the broiler chickens production system (Amer et al. 2010, Cervantes et al. 2020). Seven species of Eimeria spp. can parasitize broilers and each of them parasites a specific region of the intestine: Eimeria acervulina (duodenum), Eimeria brunetti (colon), Eimeria maxima (jejunum), Eimeria mitis (ileum), Eimeria necatrix (jejunum), Eimeria praecox (duodenum), and Eimeria tenella (cecum) (Cervantes et al. 2020). However, the infections can be caused by more than one species simultaneously (Rose \& Long 1962, Huang et al. 2017).

The identification of Eimeria species has traditionally been carried out by the morphology and morphometry of sporocysts and oocysts present in the feces and litters of the aviaries. However, they have a poor relationship with the impact of the parasite on the performance of a flock, as they only show the presence of oocysts in the feces, but do not indicate the degree/score of intestinal damage caused by the parasite (Long \& Joyner 1984). These two methodologies require qualified labor for species differentiation and identification (Long \& Joyner 1984, Haug et al. 2008), and must be combined with another diagnostic technique (Williams et al. 1996).

The classic diagnosis of coccidiosis is made by macroscopic assessment of the intestine using a methodology described by Johnson \& Reid (1970), which consists of the observation of specific lesions in the duodenum, jejunum, ileum, cecum, and colon. Clinical signs, flock history, and macroscopic assessment of the intestine indicate the species involved (Long
\& Joyner 1984). The intestinal lesions caused by E. acervulina, E. maxima, and E. tenella are considered the most important in the production of broiler chickens since they have been shown to cause the most significant impact on zootechnical indicators. Therefore, lesions in the intestine caused by these species are prioritized in intestinal health monitoring (Toledo et al. 2011, Gazoni et al. 2015, Gazoni et al. 2017, Huang et al. 2017). The histopathological analysis is used to assist in the diagnosis of macroscopic lesions in the intestine, which also helps to establish the severity of infection by Eimeria spp. (Kawazoe et al. 2005, Belote et al. 2019).

The development of molecular methods for analyzing Eimeria spp. has become essential to assist in the diagnosis of different species (Morris et al. 2007), detect subclinical infection (Morgan et al. 2009), and study its prevalence (Carvalho et al. 2011, Lan et al. 2017). The emergence of the polymerase chain reaction (PCR) allowed the analyzes with fewer parasites and the precise identification of the seven species of Eimeria spp. (Fernandez et al. 2003a, 2003b, Moraes et al. 2015, Lan et al. 2017).

Coccidiosis can be subclinical depending on the species, score of infection, and the preventive measures used to control it (Allen \& Fetterer 2002). This difficult diagnosis prevents the poultry industry from employing the best strategy for its control (Shirzad et al. 2011). This work aims to compare the effectiveness of macroscopic, histopathological, and PCR evaluation for the diagnosis of Eimeria spp. in broiler chickens.

\section{MATERIALS AND METHODS}

Research location and material collection. The research was carried out using 64 flocks of female broilers (broiler grillers), strain Cobb $500^{\mathrm{TM}}$, with an average age of 29 days (27 to 32 days), and with an average slaughter weight of $1.407 \mathrm{~kg}$. All samples were derived from a slaughterhouse that is inspected by the Federal Service, in the state of Santa Catarina, Brazil, from October 2017 to April 2018. Eight broilers from each flock were randomly removed from the slaughter line, in a total of 512 samples. The intestines were collected to perform macroscopic, histopathological, and PCR analyzes. All flocks received the same preventive treatment with anticoccidials, established by the poultry integration company.

Macroscopic evaluation of the intestines. A macroscopic evaluation of eight intestines from each flock was performed and the characteristic lesions caused by each species of Eimeria were observed, according to the classification described by Johnson \& Reid (1970), with modifications according to the reclassification of Eimeria species. The following criteria were considered for classification of macroscopic scores, for each species of Eimeria: Score 0: no gross lesions for all Eimeria species.

Eimeria acervulina (duodenum). Score 1: scattered transverse white plaques. They may be seen from either the serosal or mucosal intestinal surfaces. They may range up to a maximum of 5 lesions per square centimeter; Score 2: lesions are most closer together, but not coalescent. The intestinal walls show no thickening. Digestive tract contents are normal; Score 3: lesions are numerous and coalescent. The intestinal wall is thickened and the contents are watery. Lesions may extend as far posterior as the yolk sac diverticulum; Score 4: completely coalescent lesions in the mucosa of the duodenum, with a grayish appearance. Jejunum with transverse white plaques. Thick mucosa with cell desquamation.

Eimeria maxima (jejunum). Score 1: small red petechiae may appear on the serosal side of the mid-small intestine, though small 
amounts of orange mucus may be present; Score 2: serosal surface may be speckled with numerous red petechiae. The intestine may be filled with orange mucus, little or no ballooning of the intestine, and thickening of the wall; Score 3: intestinal wall is ballooned and thickened. The mucosal surface is roughened, a large number of petechias in the serous, and red intestinal content in the lumen; Score 4: the intestinal wall may be ballooned for most of its length, contains numerous blood clots and digested red blood cells giving a characteristic color and putrid odor. The intestinal walls is greatly thickened.

Eimeria necatrix (jejunum). Score 1: small scattered petechiae and white spots easily seen from the serosal side. Little if any damage apparent on the mucosal surface; Score 2: numerous petechiae on the serosal surface. Slight ballooning confined to the midgut area may be present; Score 3: extensive hemorrhage into the lumen of the intestine, serosal surface is covered with red petechiae and/ or white plaques. The serosal surface is rough and thickened with many pinpoint hemorrhages. Ballooning extends over lower half of small intestine; Score 4: extensive hemorrhage giving the intestine a dark color, and intestinal contents consist of red or brown mucus. Ballooning may extend throughout much of the length of the intestine.

Eimeria tenella (cecum). Score 1: few scattered petechiae on the cecal wall, and normal cecal contents present; Score 2: lesions more numerous with noticeable blood in the cecal contents, cecal wall is somewhat thickened, and normal cecal contents present; Score 3: large amounts of clotted blood and cecal walls greatly thickened. Cecum with little or no fecal content; Score 4: distended cecal wall, with blood and areas of necrosis, and fecal debris lacking.

Eimeria brunetti (colon). Score 1: intestinal wall may appear grey in color. The lower portion may be thickened, and material sloughed from the intestine are present; Score 2: intestinal wall thickened and a blood catarrhal exudate present. Transverse red streaks may be present in the lower rectum and lesions occur in the cecal tonsils; Score 3: extensive coagulation necrosis of the mucosal surface of the lower intestine may be present. Lesions may extend into the middle or upper intestine.

Histopathological evaluation of the intestines. Subsequently, $2 \mathrm{~cm}$ fragments of duodenum, jejunum, ileum, cecum, and colon were collected separately and fixed in $10 \%$ buffered formalin for 24 to 48 hours. The histological processing consisted of a total cross-section of the intestinal fragments, which were stained with hematoxylin and eosin (HE). The histological lesions were analyzed in the entire histological section of the different sections of the intestine. The lesions were classified from 0 to 4 , according to the presence of parasitic structures compatible with Eimeria spp. Score 0 was considered as the absence of the parasite, Score 1 as the presence of a slight amount of parasitic structures in less than ten villi or crypts, Score 2 as a moderate amount of parasitic structures in less than ten villi or crypts, Score 3 as presenting a moderate to large amount of parasitic structures in more than ten villi or crypts, and Score 4 with $80 \%$ to $100 \%$ of the villi or crypts affected by parasitic structures.

Research of Eimeria spp. in the intestinal content by the PCR technique. After conducting the macroscopic evaluation and collecting material for histopathology, a superficial scraping on the entire intestine was performed and all intestinal contents of the eight broilers were removed and collected a pool from each flock. The samples were placed in flasks containing $2.5 \%$ potassium dichromate solution and sent to the process of purification and rupture of the wall of the Eimeria spp. oocysts, according to Moraes et al. (2015). The extraction of nucleic acids was performed using NewGene PreAmp and Prep commercial kits according to the supplier's protocol (Simbios Biotecnologia, Cachoeirinha/RS, BR).
The primer sequences and size of the amplicons for each of the seven species of Eimeria were used, as described by Moraes et al. (2015) (Table 1). However, in our research was performed a single PCR for each species of Eimeria, to increase the sensitivity. The PCR reactions were carried out using the commercial Mastermix GeneAmp ${ }^{\circledR}$ Fast PCR Master Mix (2X) (Applied Biosystems Inc., Norwalk/CT, USA). Each reaction consisted of $20 \mu \mathrm{l}$, including $0.4 \mu \mathrm{l}$ of each Sense and Anti-Sense primer (at $10 \mu \mathrm{m}$ each), $2 \mu \mathrm{l}$ of extracted DNA, $7.2 \mu \mathrm{l}$ of nuclease-free water (Invitrogen, USA), and 10 $\mu$ l of Mastermix 2X GeneAmp ${ }^{\circledR}$ Fast PCR obtained from the supplier (Applied Biosystems Inc., Norwalk/CT, USA). The amplification was performed on the Veriti equipment (Applied Biosystems Inc., Norwalk/CT, USA) under the following conditions: a denaturation stage at $95^{\circ} \mathrm{C}$ for 10 seconds, 35 cycles of denaturation at $94^{\circ} \mathrm{C}$ for 0 second, annealing of the primers and extension of the DNA at $65^{\circ} \mathrm{C}$ for 25 seconds, with final extension stage at $72^{\circ} \mathrm{C}$ for 10 seconds. The amplification products were analyzed by agarose gel electrophoresis (2\%), stained with ethidium bromide, and observed under ultraviolet light.

Statistical analysis of the data. The results of the macroscopic, histopathological, and PCR analyzes were compiled into spreadsheets in Microsoft Office Excel to obtain the frequency of Eimeria spp. The comparison between different methods for diagnosing coccidiosis was submitted to the Kappa Cohen test, in the Microsoft Office Excel. The values obtained between 0 and 0.2 indicate a weak agreement; between 0.21 and 0.4 reasonable; between 0.41 and 0.6 moderate; between 0.61 and 0.8 strong, and between 0.81 and 1 almost perfect. The scores of lesions obtained between macroscopic and histopathological evaluations were assessed by the Wilcoxon test at $5 \%$ significance, using the Sigma Plot 12.0 program.

\section{RESULTS}

\section{Macroscopy}

The macroscopic evaluations of the flocks showed that 59.4\% (38/64) were positive for Eimeria acervulina, 32.8\% (21/64) for Eimeria maxima, 29.7\% (19/64) for Eimeria tenella, and 34.4\% (22/64) for Eimeria brunetti (Fig.1-8). None of the flock was positive for Eimeria necatrix.

Table 1. Forward (F) and reverse (R) primers used in PCR for the detection of seven Eimeria species and the size of the amplicons (SA) generated

\begin{tabular}{ccc}
\hline Designation & Sequences of primers & SA (bp) \\
\hline ac-A03-F & AGT CAG CCA CAC AAT AAT GGC AAA CAT G & 811 \\
ac-A03-R & AGT CAG CCA CAG CGA AAG ACG TAT GTG & \\
br-J18-F & TGG TCG CAG AAC CTA CAG GGC TGT & 626 \\
br-J18-R & TGG TCG CAG ACG TAT ATT AGG GGT CTG & \\
tn-K04-F & CCG CCC AAA CCA GGT GTC ACG & 539 \\
tn-K04-R & CCG CCC AAA CAT GCA AGA TGG C & \\
mt-A03-F & AGT CAG CCA CCA GTA GAG CCA ATA TTT & 460 \\
mt-A03-R & AGT CAG CCA CAA ACA AAT TCA AAC TCT AC & \\
pr-A03-F & AGT CAG CCA CCA CCA AAT AGA ACC TTG G & 354 \\
pr-A03-R & GCC TGC TTA CTA CAA ACT TGC AAG CCC T & \\
mx-A09-F & GGG TAA CGC CAA CTG CCG GGT ATG & 272 \\
mx-A09-R & AGC AAA CCG TAA AGG CCG AAG TCC TAG A & \\
nc-A18-F & TTC ATT TCG CTT AAC AAT ATT TGG CCT CA & 200 \\
nc-ENec-R & ACA ACG CCT CAT AAC CCC AAG AAA TTT TG & \\
\hline Eimeriaspecies: E. acervulina (ac),E. brunetti(br), E.tenella (tn), E. mitis (mt), \\
E. praecox(pr), E. maxima (mx), E. necatrix (nc); Source: Moraes et al. (2015).
\end{tabular}




\section{Histopathology}

The histopathological evaluation showed that $87.5 \%$ (56/64) of the flocks had at least one broiler with parasitic structures compatible with Eimeria spp. in the duodenum, $70.3 \%(45 / 64)$ in the jejunum, $18.8 \%(12 / 64)$ in the ileum, $46.9 \%(30 / 64)$ in the cecum, and $4.7 \%(3 / 64)$ in the colon. The parasitic structures compatible with Eimeria spp. were observed in the intestinal mucosa and submucosa (Fig.9-12). These structures were present in the developmental stages in schizonts, macrogamets, microgamets, and immature oocysts.

\section{Scores of lesions}

Table 2 shows the evaluation of lesion score, the number of positivity in each analysis, and the statistical significance between the scores of macroscopic and histopathological lesions for Eimeria spp. in the broilers evaluated.

\section{PCR}

The results obtained by PCR showed $21.9 \%(14 / 64)$ of the flocks were positive for E. acervulina, $12.5 \%(8 / 64)$ for $E$. maxima, 3.1\% (2/64) for Eimeria mitis, and 32.8\% (21/64) for
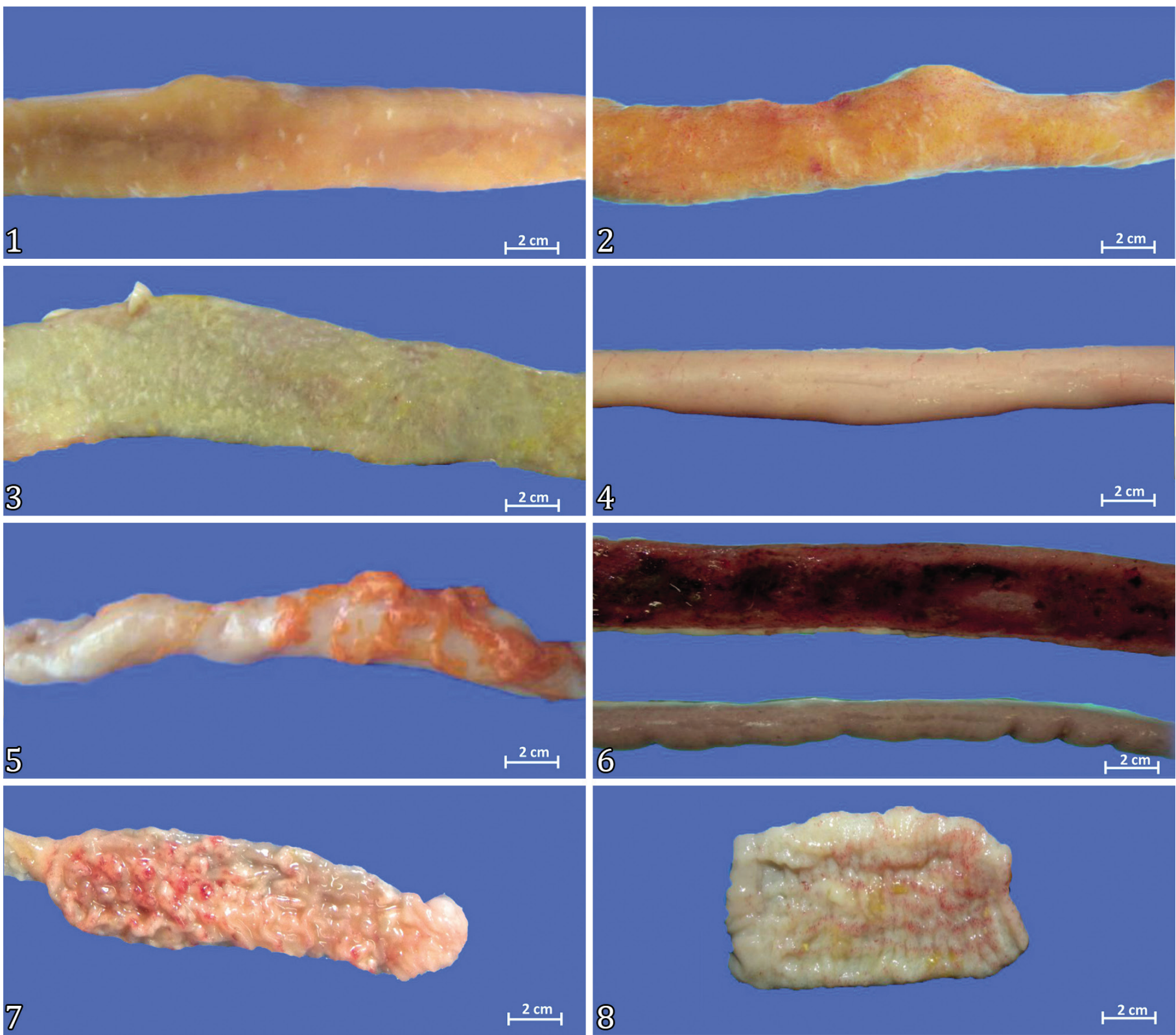

Fig.1-8. Macroscopic evaluation of Eimeria spp. in broiler chickens: (1) Eimeria acervulina Score 1 in the duodenum with white plaques dispersed in the mucosa. (2) Eimeria acervulina Score 2 with non-coalescing white plaques in the mucosa. (3) Eimeria acervulina Score 3 with a thickened intestinal wall, abundant and coalescing white plaques. (4) Eimeria maxima Score 1 in the jejunum with small red petechias dispersed in the serous. (5) Eimeria maxima Score 2 with thickening of the intestinal wall and orange mucous. (6) Eimeria maxima Score 3 with ballooning and thickening of the intestinal wall, with a large number of petechias in the serous and red intestinal content in the lumen. (7) Eimeria tenella Score 1 in the cecum with petechias dispersed in the mucosa. (8) Eimeria brunetti Score 1 in the colon with red areas in the mucosa. 
E. tenella. Eimeria brunetti, E. necatrix, and Eimeria praecox were not detected with PCR.

\section{Concordance test}

Table 3 presents the results of the Kappa Cohen test between macroscopy, histopathology, and PCR.

\section{DISCUSSION}

The data presented in this work showed a difference in the results of the coccidiosis diagnoses between the three methods evaluated. The diagnosis of Eimeria spp. exclusively by macroscopic evaluation flawed. The agreement test between histopathology and macroscopy demonstrated a weak correlation, and many flocks that showed no macroscopic lesions had different scores of parasitism in the histopathological analysis. Other studies using both methodologies have also shown that histopathology contributed to the correct diagnosis of coccidiosis and that using macroscopic evaluation alone may not represent the true magnitude of infection by Eimeria spp. (Idris et al. 1997, Santiani 2020).

Histopathology proved to be an objective method to analyze infection by Eimeria spp. However, using this technique alone is not enough to define the infecting species. Each species parasites specific regions in the intestine but some overlap in the same intestinal portion. Depending on the severity of the infection, the species can expand to other intestinal segments, which makes diagnosis difficult. Eimeria acervulina and Eimeria praecox parasitize the duodenum. Eimeria maxima develops in the mid-small intestine, but can be found in the duodenum in severe infections. It can also overlap with Eimeria necatrix, which develops from the small large intestine to the ileum, where asexual reproduction occurs, but migrates to the cecum where it undergoes sexual reproduction. Eimeria tenella cycle occurs in the cecum, but at the ileocecal junction, it can overlap with E. brunetti, which also parasites the colon,
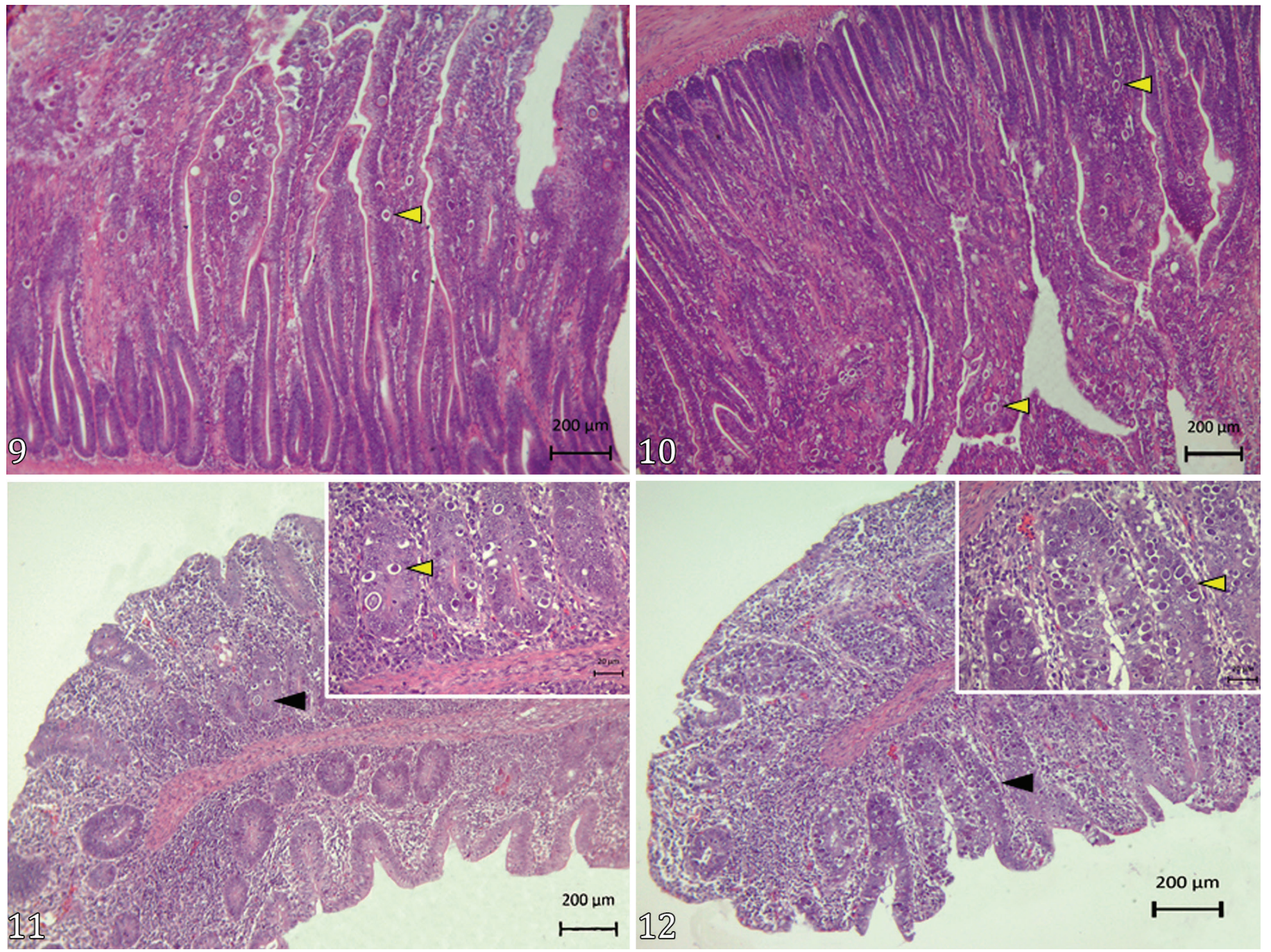

Fig.9-12. Histopathological characterization of Eimeria spp. in broiler chickens: (9) Duodenum: Score 2 lesion with a moderate amount of immature oocysts in less than ten villi (head of the yellow arrow). HE, bar $=200 \mu \mathrm{m}$. (10) Jejunum: Score 2 lesion with a moderate amount of immature oocysts in less than ten villi (head of the yellow arrow). HE, bar $=200 \mu m$. (11) Cecum: Score 1 lesion with a discrete amount of parasites (head of the black arrow) in less than ten crypts. The immature oocysts (head of the yellow arrow) are highlighted. HE, bar $=200 \mu \mathrm{m}$. (12) Cecum: Score 3 lesion with a large number of parasites (head of the black arrow) in more than ten crypts. The immature oocysts (head of the yellow arrow) are highlighted. HE, bar $=200 \mu \mathrm{m}$. 
and with E. mitis, which parasites the final part of the small intestine (Cervantes et al. 2020).

The cecum was the intestinal segment that showed the best correlation between diagnostic methods, with a moderate agreement between macroscopy versus histopathology and macroscopy versus PCR, and strong agreement between histopathology and PCR. This may have occurred due to the higher amount of intestinal content on this segment in all samples collected, which resulted in a higher presence of oocysts for PCR. Furthermore, E. tenella has characteristic macroscopic lesions, which facilitates its identification. The duodenum and jejunum generally presented a weak agreement between the variables tested and a significant difference between the scores of macroscopic and histopathological lesions (Santiani 2020).

The PCR was negative for E. necatrix and there were no macroscopic lesions in the ileum characteristic of this species. The parasitic structures in the ileum may be related to E. maxima that develop in the jejunum but can go to the ileocecal junction, or with E. mitis, which can parasitize this region (Cervantes et al. 2020).

The broilers showed higher positivity in macroscopy compared to histopathology in the colon, and the PCR was negative for $E$. brunetti. The macroscopic evaluation of the colon routinely showed red streaks in the mucosa due to the contraction of smooth muscle after the death of the bird, which are vices or tigroid plaques, a post mortem alteration with no pathological importance (Zachary \& McGavin 2012). However, in the macroscopic lesion score established by Johnson \& Reid (1970) considers it a mild macroscopic lesion of E. brunetti.
There was a significant difference between Score 0 of macroscopic and histopathological lesion in all intestinal segments and Score 1 in the duodenum, jejunum, ileum, and colon. Thus, macroscopy can not detect Eimeria spp. at mild infections. The difference can also be observed in Score 3, with a higher number of broilers affected in the histopathological analysis. Only one broiler with Score 4 was found on histopathological examination, which presented Score 2 on macroscopy. Another study, which evaluated broiler flocks of similar age and used the same lesion classification, showed a significant difference in Score 0 in the duodenum, ileum, and cecum, Score 1 in the ileum and cecum, and Score 2 in the duodenum, where the histopathological analysis was also more efficient (Santiani 2020).

In a previous study, E. acervulina and E. maxima were investigated in the duodenum and jejunum using macroscopic analysis, according to Johnson \& Reid (1970) and using the histopathological evaluation score from 0 to 4 according to the distribution of the different stages of reproduction of Eimeria in the intestinal segment plus the severity of the infection. There was a significant difference in Scores 1 and 2 for the duodenum and jejunum and in Score 3 for the duodenum, with a higher number of positive broilers in the histopathological analysis (Idris et al. 1997). Another study investigated $E$. maxima with a macroscopic, histopathological evaluation, and a score for the number of oocysts per gram of feces. The histopathological analysis was superior to the oocyst count and macroscopic evaluation (Goodwin et al. 1998).

In the present study, PCR results were lower than those obtained by histopathology. This was possibly due to the small number of oocysts in the intestinal content since the

Table 2. Frequencies of the macroscopic and histopathological lesions for each intestinal segment in the different scores of lesions by Eimeria spp. in broiler chickens

\begin{tabular}{|c|c|c|c|c|c|c|c|c|c|c|}
\hline \multirow{2}{*}{ Score } & \multicolumn{5}{|c|}{ Macroscopic lesions } & \multicolumn{5}{|c|}{ Histopathological lesions } \\
\hline & Duod. & Jejun. & Ileum & Cecum & Colon & Duod. & Jejun. & Ileum & Cecum & Colon \\
\hline 0 & $\begin{array}{l}71.5 \% \\
\text { (366)a }\end{array}$ & $\begin{array}{l}93.9 \% \\
(481) a\end{array}$ & $\begin{array}{c}100 \% \\
(512) a\end{array}$ & $\begin{array}{l}92.6 \% \\
(474) a\end{array}$ & $\begin{array}{l}80.3 \% \\
\text { (411)a }\end{array}$ & $\begin{array}{l}47.8 \% \\
(245) b\end{array}$ & $\begin{array}{c}59.8 \% \\
(306) b\end{array}$ & $\begin{array}{l}94.7 \% \\
(485) b\end{array}$ & $\begin{array}{c}77.7 \% \\
\text { (398)b }\end{array}$ & $\begin{array}{l}98.8 \% \\
(506) b\end{array}$ \\
\hline 1 & $\begin{array}{l}23.2 \% \\
\text { (119)a }\end{array}$ & $\begin{array}{l}5.7 \% \\
\text { (29)a }\end{array}$ & $\begin{array}{c}0 \% \\
(0) a\end{array}$ & $\begin{array}{l}7.2 \% \\
\text { (37)a }\end{array}$ & $\begin{array}{l}19.7 \% \\
(101) a\end{array}$ & $\begin{array}{l}40.0 \% \\
(205) b\end{array}$ & $\begin{array}{c}26.8 \% \\
(137) \mathrm{b}\end{array}$ & $\begin{array}{l}4.1 \% \\
(21) b\end{array}$ & $\begin{array}{c}12.3 \% \\
(63) a\end{array}$ & $\begin{array}{c}1.2 \% \\
(6) \mathrm{b}\end{array}$ \\
\hline 2 & $\begin{array}{l}4.5 \% \\
(23) a\end{array}$ & $\begin{array}{l}0.2 \% \\
\text { (1)a }\end{array}$ & $\begin{array}{c}0 \% \\
(0) a\end{array}$ & $\begin{array}{c}0.2 \% \\
(1) a\end{array}$ & - & $\begin{array}{l}6.4 \% \\
(33) a\end{array}$ & $\begin{array}{l}3.1 \% \\
\text { (16)a }\end{array}$ & $\begin{array}{l}0.4 \% \\
(2) a\end{array}$ & $\begin{array}{l}2.5 \% \\
(13) a\end{array}$ & - \\
\hline 3 & $\begin{array}{l}0.8 \% \\
(4) \mathrm{a}\end{array}$ & $\begin{array}{c}0.2 \% \\
(1) a\end{array}$ & $\begin{array}{l}0 \% \\
(0) a\end{array}$ & $\begin{array}{c}0 \% \\
(0) a\end{array}$ & - & $\begin{array}{l}5.7 \% \\
(29) b\end{array}$ & $\begin{array}{l}10.4 \% \\
\text { (53)b }\end{array}$ & $\begin{array}{c}0.8 \% \\
(4) a\end{array}$ & $\begin{array}{l}7.2 \% \\
(37) b\end{array}$ & - \\
\hline 4 & - & - & - & $\begin{array}{l}0 \% \\
(0) a\end{array}$ & - & - & - & - & $\begin{array}{l}0.2 \% \\
(1) \mathrm{b}\end{array}$ & - \\
\hline
\end{tabular}

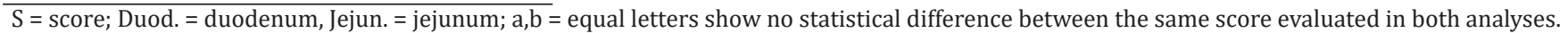

Table 3. Agreement between the macroscopy, histopathology, and PCR of Eimeria spp. for each intestinal segment in broiler chickens

\begin{tabular}{cccc}
\hline \multirow{2}{*}{ Intestinal segment } & \multicolumn{3}{c}{ Variables tested } \\
\cline { 2 - 4 } & Macroscopy/Histopathology & Histopathology/PCR & Macroscopy/PCR \\
\hline Duodenum & 0.16 & 0.03 & 0.12 \\
Jejunum & 0.19 & 0.11 & 0.28 \\
Ileum & $0^{*}$ & 0.25 & $0 *$ \\
Cecum & 0.52 & 0.65 & 0.49 \\
Colon & 0.08 & $0^{*}$ & $0 *$
\end{tabular}

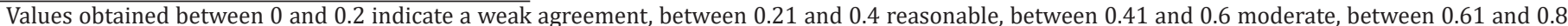
strong, and between 0.81 and 1 almost perfect; * No positive cases in both tests. 
broilers were fasted in the pre-slaughter period to perform intestinal cleaning and avoid contamination in the carcasses. Another research with PCR of feces from the poultry litter obtained the best result, with 96\% (Moraes et al. 2015), 91\% (Györke et al. 2013), and 87.75\% (Huang et al. 2017) of positive flocks. In the molecular diagnosis, E. mitis and $E$. praecox showed a frequency of $3.1 \%$ and $0 \%$, respectively. As a macroscopic diagnosis is not possible, it is essential to use molecular techniques to verify the presence of these species (Meireles et al. 2004, Carvalho et al. 2011).

The literature presented no studies comparing the results of the three methodologies used in the present study for the diagnosis of coccidiosis. A survey with three diagnostic techniques showed that the macroscopic evaluation had a lower frequency of Eimeria spp. infection compared to morphology and that PCR was more efficient in identifying Eimeria species (Carvalho et al. 2011). Another study performed on Eimeria spp. by morphology and morphometry showed a higher number of positive flocks, followed by histopathological analysis and, finally, by macroscopic evaluation (Santiani 2020).

Some studies even apply macroscopy with parasitological exams to monitor infection by Eimeria spp. (Shirzad et al. 2011, Gazoni et al. 2017, Lan et al. 2017, Debbou-Iouknane et al. 2018). The identification of Eimeria spp. by histopathology is used in experimental observations to measure the impact of the disease on zootechnical indicators such as mortality, daily weight gain, and feed conversion (Amer et al. 2010, Kawahara et al. 2014, Belote et al. 2019), as well as in evaluations of lesions in the intestinal wall caused by Eimeria spp. infections (Debbou-Iouknane et al. 2018). This technique is also applied to assess the effectiveness of anticoccidials drugs (Zhang et al. 2012, She et al. 2017, Fortuoso et al. 2019) and vaccines (Jeffers 1975, Song et al. 2016, Suprihati \& Yunus 2018). However, our research data shows that histopathology also has practical applicability in the diagnosis of coccidiosis.

\section{CONCLUSION}

Macroscopic diagnosis can generate false-negative results, especially in mild infections. Some criteria for the macroscopic lesion score established by Johnson \& Reid (1970) must be reviewed.

The histopathological examination proved to be effective in diagnosing coccidiosis regardless of the intensity of parasitism. The histological lesion score can be used in the diagnostic routine. PCR using a sample of intestinal contents from fasted broilers from a slaughterhouse was not effective in identifying flocks positive for Eimeria spp.

The histopathological analysis associated with macroscopic evaluation is the most suitable form for diagnosis, and is important include the PCR to assist in the identification of the seven species of Eimeria present in the broiler chickens flocks.

Acknowledgements.- This work was supported by “Fundação de Amparo à Pesquisa e Inovação de Santa Catarina" (FAPESC), Brazil (04/2018, 2019TR608) and by the "Coordenação de Aperfeiçoamento de Pessoal de Nível Superior" (CAPES) with the Graduation Support Program (PROAP).

Conflict of interest statement.- The authors declare that they have no competing interests.

\section{REFERENCES}

Allen P.C. \& Fetterer R.H. 2002. Recent advances in biology and immunobiology of Eimeria species and in diagnosis and control of infection with these coccidian parasites of poultry. Clin. Microbiol. Rev. 15(1):58-65. <https:// dx.doi.org/10.1128/CMR.15.1.58-65.2002><PMid:11781266>

Amer M.M., Awaad M.H.H., El-Khateeb R.M., Abu-Elezz N.M.T.N., Sherein-Said A., Ghetas M.M. \& Kutkat M.A. 2010. Isolation and identification of Eimeria from field coccidiosis in chickens. J. Am. Sci. 6(10):1107-1114.

Belote B.L., Soares Y., Tujimoto-Silva A., Sanches A.W.D., Kraieski A.L. \& Santin E. 2019. Applying I see inside histological methodology to evaluate gut health in broilers challenged with Eimeria. Vet. Parasitol. 276(Supl.):100004 <https://dx.doi.org/10.1016/j.vpoa.2019.100004><PMid:34311934>

Carvalho F.S., Wenceslau A.A., Teixeira M., Carneiro J.A.M., Melo A.D.B. \& Albuquerque G.R. 2011. Diagnosis of Eimeria species using traditional and molecular methods in field studies. Vet. Parasitol. 176(2/3):95-100 <https://dx.doi.org/10.1016/j.vetpar.2010.11.015><PMid:21167646>

Cervantes H.M., McDougald L.R. \& Jenkins M.C. 2020. Protozoal infections, p.1193-1217. In: Swayne D.E., Boulianne M., Logue C.M., McDougald L.R., Nair V. \& Suarez D.L. (Eds), Diseases of Poultry. 14th ed. John Wiley and Sons, Hoboken, NJ.

Debbou-Iouknane N., Benbarek H. \& Ayad A. 2018. Prevalence and aetiology of coccidiosis in broiler chickens in Bejaia province, Algeria. Onderstepoort J. Vet. Res. 85(1):1-6. <https://dx.doi.org/10.4102/ojvr.v85i1.1590> $<$ PMid:30326718>

Fernandez S., Costa A.C., Katsuyama A.M., Madeira A.M.B.N. \& Gruber A 2003b. A survey of the inter- and intraspecific RAPD markers of Eimeria spp. of the domestic fowl and the development of reliable diagnostic tools. Parasitol. Res. 89(6):437-445. <https://dx.doi.org/10.1007/s00436-0020785-2><PMid:12658454>

Fernandez S., Pagotto A.H., Furtado M.M., Katsuyama A.M., Madeira A.M.B.N \& Gruber A. 2003a. A multiplex PCR assay for the simultaneous detection and discrimination of the seven Eimeria species that infect domestic fowl. Parasitology 127(Pt 4):317-325. <https://dx.doi.org/10.1017/ s0031182003003883><PMid:14636018>

Fortuoso B.F., Dos Reis J.H., Gebert R.R., Barreta M., Griss L.G., Casagrande R.A., Cristo T.G., Santiani F., Campigotto G., Rampazzo L., Stefani L.M., Boiago M.M., Lopes L.Q., Santos R.C.V., Baldissera M.D., Zanette R.A., Tomasi T. \& Da Silva A.S. 2019. Glycerol monolaurate in the diet of broiler chickens replacing conventional antimicrobials: Impact on health, performance and meat quality. Microb. Pathog. 129:161-167.<https://dx.doi.org/10.1016/j. micpath.2019.02.005> <PMid:30735801>

Gazoni F.L., Adorno F.C., Lovato M., Dilkin P., Hermes S., Magro Junior. P.R., Pacheco P.S., Dalmagro M., Felin M.R., Hernandez-Velasco X. \& Tellez G. 2015 Coccidiosis prevalence and correlation with intestinal health of broilers in Brazilian agricultural industries between the years 2012 and 2014. Int. J. Poult. Sci. 14(9):511-515.<https://dx.doi.org/10.3923/ijps.2015.511.515>

Gazoni F.L., Adorno F.C., Matte F., Malta T., Felin M.R., Urbano T., Zampar A., Hernandez-Velasco X \& Tellez G. 2017. Study of the correlation between intestinal health and prevalence of coccidiosis in broiler chickens of Brazilian agribusinesses between the years 2015 and 2016. Int. J. Poult. Sci. 16(10):381-386. <https://dx.doi.org/10.3923/ijps.2017.381.386>

Goodwin M.A., Brown J. \& Bounous D.I. 1998. Use of microscopic lesion scores, gross lesion scores and oocyst count scores to detect Eimeria maxima in chickens. Avian Pathol. 27(4):405-408. <https://dx.doi. org/10.1080/03079459808419359 > <PMid:18484020>

Györke A., Pop L. \& Cozma V. 2013. Prevalence and distribution of Eimeria species in broiler chicken farms of different capacities. Parasite 20:50 <https://dx.doi.org/10.1051/parasite/2013052> <PMid:24309007>

Haug A., Gjevre A.-G., Thebo P., Mattsson J.G. \& Kaldhusdal M. 2008. Coccidial infections in commercial broilers: epidemiological aspects and comparison of Eimeria species identification by morphometric and polymerase chain 
reaction techniques. Avian Pathol. 37(2):161-170. <https://dx.doi. org/10.1080/03079450801915130 > <Mid:18393094>

Huang Y., Ruan X., Li L. \& Zeng M. 2017. Prevalence of Eimeria species in domestic chickens in Anhui province, China. J. Parasit. Dis. 41(4):1014-1019. <https://dx.doi.org/10.1007/s12639-017-0927-1> <PMid:29114135>

Idris A.B., Bounous D.I., Goodwin M.A., Brown J. \& Krushinskie E.A. 1997. Lack of correlation between microscopic lesion scores and gross lesion scores in commercially grown broilers examined for small intestinal Eimeria spp. coccidiosis. Avian Dis. 41(2):388-391. <PMid:9201404>

Jeffers T.K. 1975. Attenuation of Eimeria tenella through selection for precociousness. J. Parasitol. 61(6):1083-1090. <PMid:1195070>

Johnson J. \& Reid W.M.1970. Anticoccidial drugs: lesion scoring techniques in battery and floor-pen experiments with chickens. Exp. Parasitol. 28(1):30-36. <https://dx.doi.org/10.1016/0014-4894(70)90063-9><PMid:5459870>

Kawahara F., Zhang G., Suzuki T., Iwata A., Nagamune K. \& Nunoya T. 2014. Characterization of Eimeria brunetti isolated from a poultry farm in Japan. J. Vet. Med. Sci. 76(1):25-29. <https://dx.doi.org/10.1292/jvms.13-0239> $<$ PMid:23965940>

Kawazoe U., Bordin E.L., Lima C.A. \& Dias L.A.V. 2005. Characterisation and histopathological observations of a selected Brazilian precocious line of Eimeria acervulina. Vet. Parasitol. 131(1/2):5-14. <https://dx.doi. org/10.1016/j.vetpar.2005.03.038><PMid:15923086>

Lan L.-H., Sun B.-B., Zuo B.-X.-Z., Chen X.-Q. \& Du A.-F. 2017. Prevalence and drug resistance of avian Eimeria species in broiler chicken farms of Zhejiang province, China. Poult. Sci. 96(7):2104-2109. <https://dx.doi. org/10.3382/ps/pew499><PMid:28339722>

Long P.L. \& Joyner L.P. 1984. Problems in the identification of species of Eimeria. J. Protozool. 31(4):535-541. <https://dx.doi.org/10.1111/j.1550-7408.1984. tb05498.x><PMid:6392531>

Meireles M.V., Roberto L.O. \& Riera R.F. 2004. Identification of Eimeria mitis and Eimeria praecox in broiler feces using polymerase chain reaction. Brazilian J. Poult. Sci. 6(4):249-252. <https://dx.doi.org/10.1590/S1516635X2004000400010>

Moraes J.C., França M., Sartor A.A., Bellato V., Moura A.B., Magalhães M.L.B., Souza A.P. \& Miletti L.C. 2015. Prevalence of Eimeria spp. in broilers by Multiplex PCR in the southern region of Brazil on two hundred and fifty farms. Avian Dis. 59(2):277-281. <https://dx.doi.org/10.1637/10989112014-Reg > <PMid:26473679>

Morgan J.A.T., Morris G.M., Wlodek B.M., Byrnes R., Jenner M., Constantinoiu C.C., Anderson G.R., Lew-Tabor A.E., Molloy J.B., Gasser R.B. \& Jorgensen W.K. 2009. Real-time polymerase chain reaction (PCR) assays for the specific detection and quantification of seven Eimeria species that cause coccidiosis in chickens. Mol. Cell. Probes 23(2):83-89. <https://dx.doi. org/10.1016/j.mcp.2008.12.005><PMid:19141318>

Morris G.M., Woods W.G., Richards D.G. \& Gasser R.B. 2007. The application of a polymerase chain reaction (PCR)-based capillary electrophoretic technique provides detailed insights into Eimeria populations in intensive poultry establishments. Mol. Cell. Probes 21(4):288-294.<https://dx.doi. org/10.1016/j.mcp.2007.03.001><PMid:17448632>

Quiroz-Castañeda R.E. \& Dantán-González E. 2015. Control of avian coccidiosis: future and present natural alternatives. Biomed. Res. Int. 2015:430610. <https://dx.doi.org/10.1155/2015/430610> <PMid:25785269>

Rose M.E. \& Long P.L. 1962. Immunity to four species of Eimeria in fowls. Immunology 5(1):79-92. <PMid:14493839>

Santiani F. 2020. Caracterização anatomopatológica e parasitológica da coccidiose em frangos de corte e sua possível associação com infecções bacterianas secundárias. Master's Thesis, Universidade do Estado de Santa Catarina, Lages, SC. 93p.

She R., Fei C., Chen H., Wang X., Wang M., Zhang K., Zhang L., Wang C., Liu Y., Zheng W. \& Xue F. 2017. Action of nitromezuril against Eimeria tenella with clinically anticoccidial indices and histopathology. Parasitol. Res. 116(8):2167-2174. <https://dx.doi.org/10.1007/s00436-017-5520-0> $<$ PMid:28589234>

Shirzad M.R., Seifi S., Gheisari H.R., Hachesoo B.A., Habibi H. \& Bujmehrani H. 2011. Prevalence and risk factors for subclinical coccidiosis in broiler chicken farms in Mazandaran province, Iran. Trop. Anim. Health Prod. 43(8):1601-1604. <https://dx.doi.org/10.1007/s11250-011-9876-3> <PMid:21626064>

Song X., Zhang Z., Liu C., Xu L., Yan R. \& Li X. 2016. Evaluation of the persistence, integration, histopathology and environmental release of DNA vaccine encoding Eimeria tenella TA4 and chicken IL-2. Vet. Parasitol. 229:22-30. <https://dx.doi.org/10.1016/j.vetpar.2016.09.010 > <PMid:27809974>

Suprihati E. \& Yunus M. 2018. Evaluation of the antigenicity and immunogenicity of Eimeria tenella by reproductive index and histopathological changes of cecal coccidiosis virulent live vaccine in broiler chickens. Afr. J. Infect. Dis. 12(1 Supl.):104-110. <https://dx.doi.org/10.2101/Ajid.12v1S.15> <PMid:29619439>

Toledo G.A., Almeida J.D.M., Almeida K.S. \& Freitas F.L.C. 2011. Coccidiosis in broiler chickens raised in the Araguaína region, State of Tocantins, Brazil. Revta Bras. Parasitol. Vet. 20(3):249-252. <https://dx.doi.org/10.1590/ S1984-29612011000300014>

Williams R.B., Bushell A.C., Reperant J.M., Doy T.G., Morgan J.H., Shirley M.W., Yvore P., Carr M.M. \& Fremont Y. 1996. A survey of Eimeria species in commercially-reared chickens in France during 1994. Avian. Pathol. 25(1):113-130. <https://dx.doi.org/10.1080/03079459608419125> $<$ PMid:18645842>

Zachary J.F. \& McGavin M.D. 2012. Pathologic Basis of Veterinary Disease. 5th ed. Elsevier Mosby, St. Louis, p.322-404.

Zhang D.-F., Sun B.-B., Yue Y.-Y., Yu H.-J., Zhang H.-L., Zhou Q.-J. \& Du A.-F. 2012. Anticoccidial effect of halofuginone hydrobromide against Eimeria tenella with associated histology. Parasitol. Res. 111(2):695-701.<https://dx.doi. org/10.1007/s00436-012-2889-7><PMid:22415441> 